\title{
The Effect of Back Translation on Students' Translation Achievement
}

\author{
Musrida Yanti ${ }^{1, *}$, Herwamati Syarif ${ }^{1}, \operatorname{Hamzah}^{1}$ \\ ${ }^{l}$ Department of English Education, Faculty of Language and Art, Universitas Negeri Padang, Padang, Indonesia \\ *Email: yantimusrida@gmail.com
}

\begin{abstract}
This research is aimed at finding out the effect of back translation technique on students' translation achievements at the sixth semester students of English Department of IAIN Bukittinggi. Design of the research is quasi experimental with $2 \times 2$ factorial design. The population of this research is the sixth semester students in academic year 2018/2019 consisted of 3 classes (78 students). Cluster random sampling is used to choose the sample, class A as the experimental class (26 students) and class B as the control class (28 students). Translation test is an instrument to get data from the students. The result of the research shows that: students who are taught by using back translation technique achieve better translation achievement. It can be concluded that back translation had a significant effect on students' achievement in translation.
\end{abstract}

Keywords: back translation, translation, technique

\section{INTRODUCTION}

In the era of information, one needs to be familiar with the information technology as almost every part of human life have been immensely associated with technology, from work, education, entertainment, and even daily necessities. Everything is related to the outcome of science and information technology. Thus, those who are unable to recognize the importance of acquiring information technology will be foreigner in life.

Nowadays changing information among countries in the world is not limited. Everyone is able to gain the same information despite living in different countries. The information is generally written in English since it is an international language. It shows that English is a bridge for everyone to gain information from different languages to their owns. Thus, people have to learn English in order to get clear information. Unfortunately, not all people are able to use English for communication.

Translation is included in English education department curriculum in the most universities in Indonesia. Eventhough the students of English education are prepared to be an English teacher, they also have to have anaditional skill which is called translation. The goal is not only for educational purposes, but also for students to have additional skill that will greatly help them in the future. According to Liu \& Zhao[1], the goal of English teaching in universities is to train the students to comprehensively use the languages in listening, speaking, reading, writing, also translation. It means that the university ought to be geared to improve students' language skills

Recently, there is a technique used in translation field, called back translation technique. Brislin[2] state that back-translation is translating from the target language back to the source language and the equivalence between source and target versions can be evaluated. Therefore, back translation is applied to achieve the equivalence. In short, back translation is an important technique since it helps the students to create a good and qualified translation because it provides the real document to be compared.

There have been some studies related to the implementation of back translation technique in teaching translation. Chen \& Boore[2], they conduct a research to examine the effects of the procedure of translation and the techniques used on the collection and interpretation of original language qualitative data for English presentation. He discussed about the factors influencing the quality of translation including translator, back-translation, culture and language. Ozolins[3], his research presents a case study of the translation of a medical diagnostic tool for prioritizing hip and knee surgery in Melbourne, Australia, which employed a back translation methodology and resulted in robust interaction between authors and translators. The use of back translation technique in translation will inform studnets about their develop language and culture awareness. Therefore, the implementation is worth a try.

Even though several studies have revealed the benefit of back translation technique, this study is still important. In Indonesia, the study on translation for teaching translation is still very limited and inconclusive. Thus, this research will try to investigate the effect of back translation on students' translation achievement. 


\section{RELEVANT THEORETICAL REVIEWS}

\subsection{Translation}

Translation has been defined by many experts. Newmark[4] considers translation as a craft in which the translator tries to replace a written message in one language by the same message in another language. Nida $\&$ Taber[5] define that translation is creating the closest natural equivalent of the SL message in the TL language. Briefly, translation is an activity to transfer or reproduce the idea or messages equivalently from the SL into the TL.

In order to create a qualified translation, translators are required to have several skills Calvo[6] mentioned that a translator focus on descriptive, more theoretical translational conceptions of language, intercultural transfer, (literary) translation analysis, linguistics, etc. In a line with, Madgeburg[7] provides several abilities that a professional translator has to have; a. professional knowledge, b. metacommunicative competence, c. intercultural competence, d. Distribution, e. writing abilities, f. media competence, g. research competence, h. stress resistence, and i.self-assertion and self-assurance or self confidence.

Briefly, translation is an activity to transfer or reproduce the idea or messages equivalently from the SL into the TL. It is not only transferring words in a text into another language, but also transferring the meaning contained in the text equivalently..

\subsection{Teaching Translation by Using Back Translation Technique}

Teaching is an occupation that produces something great when the correct beliefs and principles of teaching are achieved in the classroom. As Fry, Ketteridge, \& Marshall [8] argues that the goal of teaching is primarily to get students to fully comprehend the knowledge being examined.

Back translation requires students to translate back a translated document to the source language. Brislin[9] states that back-translation is translating from the TL back to the SL and the equivalence between source and target versions can be evaluated. Back-translation is appropriate, whether the research goals are comparative or operational, once the content of the items has been established.

In order to implement back translation technique, there are procedures that the lecturer needs to know in order to help student. The procedure is based on Zhang \& C[10]; (1) the lecturer should select an appropriate English text and prepare an L1 version, (2) the students have to translate the L1 text back into English, (3) the lecturer and the students compare the back-translated English text with the original. Briefly, it is important for lecturers to be able to select material based on their students' levels. The second step can be done independently by each student. The last, it is the time for sharing and discussing, not only among students but also with the lecturer.

\subsection{Assessing Translation}

There are two kinds of assessment in translation. They are qualitative and quantitative. Qualitative is an assessment where a description of the quality of a translation is given in terms such as excellent, very good, good, and bad or good. While quantitative links itself to qualitative through the use of score. William[11] states that, quantitative assessment is better to use than qualitative in the context of academic field; score can easily describe the quality of a translation. In conclusion, using quantitative assessment is preferable in finding out the quality of a translation.

One of the quantitative assessments is the one created by JD Edwards[12], the proposes some categories in translation assessment for assessing the translation product.

\subsection{Hypotheses}

In this research, there will be two kinds of hypotheses, namely null hypotheses (Ho) and alternative hypotheses (Ha). The hypotheses are formulated as follows:

Ho: The students who are taught by using back translation technique do not have better result in translation than those who are taught by small group discussion.

Ha: The students who are taught by using back translation technique have better result in translation that those who are taught by small group discussion.

\section{METHOD}

This research belongs to a quasi experimental research. the population of this research were the sixth semester students of English Department of IAIN Bukittinggi. There were three classes with 78 students, class A, B, and C. In this research, class $A$ was the experimental class treated by applying back translation technique, and class B was the control class treated by applying small group discussion technique.

The data were collected through translation test. For the students' translation, the researcher assigned the translation test to assess students' translation achievement after the treatment was given. The students were tested individually; they were given text to translate.

After collecting the data, researcher analyzed them to find the normality, homogeneity and hypothesis testing. Normality testing was done to see whether the data collections from both groups were normally distributed or not. It was analyzed by using Lilliefors Test. The homogeneity test was analyzed by using Variance test (Ftest). Hypotheses testing was calculated by using t-test. 
The translation test was given to both experiment class and experiment class. The result from the test can be viewed at table below:

\subsection{Results}

Table 1 Scoring range

\begin{tabular}{|c|c|c|}
\hline \multirow{2}{*}{ Range } & \multicolumn{2}{|c|}{ Frequencies } \\
\cline { 2 - 3 } & Experiment & Control \\
\hline $25-35$ & 0 & 7 \\
\hline $36-46$ & 0 & 9 \\
\hline $47-57$ & 6 & 3 \\
\hline $58-68$ & 8 & 5 \\
\hline $69-79$ & 6 & 3 \\
\hline $80-90$ & 4 & 1 \\
\hline $91-100$ & 2 & 0 \\
\hline Total & 26 & 28 \\
\hline
\end{tabular}

In the experiment class, there is no student who got the score from range 25-46, 6 students in score range 47-57, 8 students in score range 56-68, 6 students in score range 6979,4 students in score range $80-90$, and 2 students in score range 91-100. While in control class, there are 7 students in score range 25-35, 9 students in score range 36-46, 3 student in score range 47-57, 5 students in score range 58 68,3 students in score range 69-79, 1 student in score range 80-90, and there is none in score range 91-100. To make it clearer, it can be viewed on the graphic and curve below:

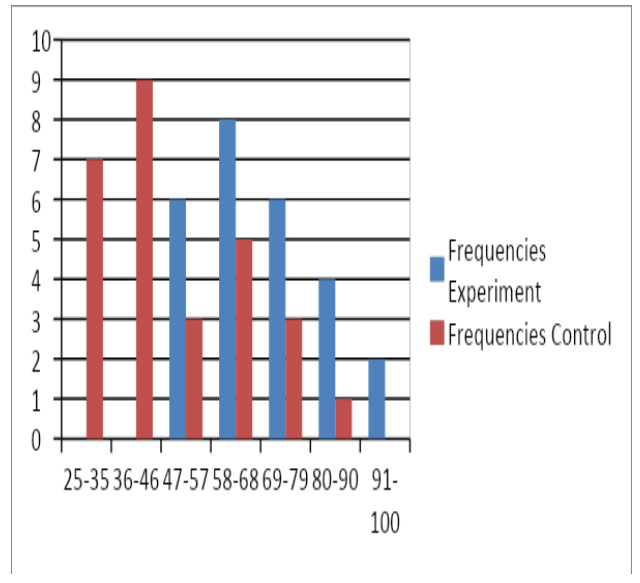

Picture 1 Students' Score Range

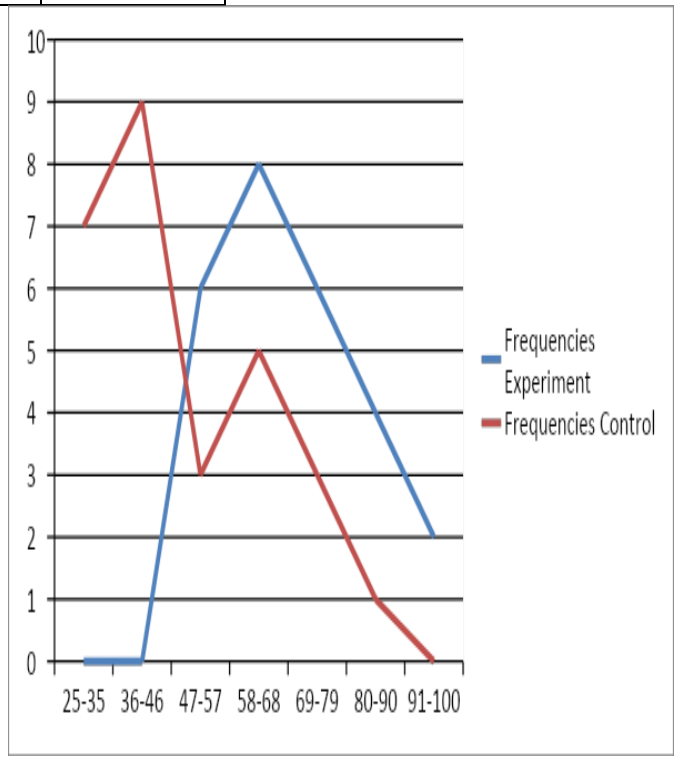

Picture 2 Curve of Students' Score Range

Based on the calculation from the test, the lowest score from the experimental class was 51 , the highest score is 96 , the mean is 68.69 , the median is 67.50 , the variance is 152.862 , and the standard deviation is 12.364 . While in the control class, the lowest score is 25 , the highest score is 82 , the mean is 47.19 , the median is 41.50 , the variance is 257.362 , and the standard deviation is 16.042 . The data can be viewed on the table below: 
Table 2 Summary of Students' Translation Score from Experimental and Control Class

\begin{tabular}{|l|r|c|c|c|c|c|c|}
\hline Class & $\mathrm{N}$ & Mean & Max & Min & Sum & SD & Var \\
\hline Experimental & 26 & 69 & 96 & 51 & 1783 & 12.36 & 153 \\
\hline Control & 28 & 47 & 82 & 25 & 1335 & 16.04 & 257 \\
\hline
\end{tabular}

From the table 4.5, it can be seen that the total score of students in experimental class is 1783 . The mean score of experimental class is 69 , which is higher than the mean score of control class 47. Then, maximum score of experimental class is 96 and minimum score is 51 . Whereas, the maximum score of control class is 82 and minimum score is 25 . It is pointed that students in experimental class have higher translation score than students in control class.

Based on the calculation from the test, the lowest score from the experimental class was 51 , the highest score is 96 , the mean is 68.69 , the median is 67.50 , the variance is 152.862 , and the standard deviation is 12.364 . While in the control class, the lowest score is 25 , the highest score is
82 , the mean is 47.19 , the median is 41.50 , the variance is 257.362 , and the standard deviation is 16.042 .

Then, the data analysis of students' translation test in experimental class and control class were analyzed through some steps. The normality and homogeneity of students' translation test score were tested. Then the hypothesis was tested using the t-test formula.

By analyzing the result of the test from the experimental class and control class by using the SPSS 22, the result is used to find out whether the test was distributed normally or not. The data is normal if sig value is higher than 0.05 and the data is not normal if the sig value is smaller than 0.05 . The output of normality test using SPSS 22 can be viewed on the table below:

Table 3 Result of normality testing of students' translation achievement Tests of Normality

\begin{tabular}{|c|c|c|c|c|c|c|}
\hline \multirow{2}{*}{} & \multicolumn{3}{|c|}{ Kolmogorov-Smirnova } & \multicolumn{3}{c|}{ Shapiro-Wilk } \\
\cline { 2 - 7 } & Statistic & Df & Sig. & Statistic & Df & Sig. \\
\hline Exp & .129 & 26 & $.200 *$ & .956 & 26 & .327 \\
Cont & .204 & 26 & .007 & .923 & 26 & .052 \\
\hline
\end{tabular}

Based on the table above, both experiment and control class have sig value higher than $0.05(0.327>0.05$ and $0.052>0.05)$. It means that the data was distributed normally.
Testing homogeneity from the test is done in order to find out whether the data from the test is homogenous or not. The output from SPSS 22 can be viewed on the table below:

Table 4 Result of homogeneity testing of students' translation achievement

\begin{tabular}{|c|c|c|c|}
\hline & & \multicolumn{2}{|c|}{ Levene's Test for Equality of Variances } \\
\hline & & $\mathrm{F}$ & Sig. \\
\hline Score & Equal variances assumed & 3.697 & .060 \\
\hline & Equal variances not assumed & & \\
\hline
\end{tabular}


From the table 4.8 , the sig value is 0.060 which is higher than 0.05 . It means that the data of the two classes is homogenous.

The t-test was done by comparing the result of the translation test of both experimental and the control classes. Alternate hypothesis was accepted if the t-measure is higher than t-table or (-)t-measure is smaller than (-)ttable. The output from SPSS 22 can be viewed on the table below:

Table 5 Result of T-test analysis of students' translation achievement

\begin{tabular}{|c|c|c|c|c|c|c|}
\hline \multirow{2}{*}{$\mathrm{T}$} & \multirow{2}{*}{ Df } & \multirow{2}{*}{ Sig. (2-tailed) } & \multirow{2}{*}{ Mean Difference } & \multirow{2}{*}{$\begin{array}{l}\text { Std. Error } \\
\text { Difference }\end{array}$} & \multicolumn{2}{|c|}{$\begin{array}{l}95 \% \text { Confidence Interval } \\
\text { of the Difference }\end{array}$} \\
\hline & & & & & Lower & Upper \\
\hline 5.272 & 52 & .000 & 20.764 & 3.938 & 12.861 & 28.667 \\
\hline
\end{tabular}

From the table 4.9, the t-observed is 5.272. The t-table for $\mathrm{Df}=52$ is 2.006 . So, the alternate hypothesis was accepted because the value of t-observed is higher than the value of t-table (5.272>2.006). It means, there is a difference between students who are taught by using back translation technique and the students who are taught by using small group discussion technique.

In conclusion, the students who were taught by using back translation technique achieve better translation than those who are taught by using small group discussion technique at the sixth semester students of English Department of IAIN Bukittinggi. It happened since in back translation technique, the students are able to compare their result with the real text, they know their gaps between their knowledge and the language itself. In addition, students enjoyed the learning process since they were given time to do it by themselves and at the end compare it together

\subsection{Discussion}

Back translation gave better result to students' translation achievement than small group discussion technique. There were many students who got good score in translation test. It happened since back translation is applied. Most of the students produce translation result which is close to the source language. That way, they became aware of their own shortcoming and improve them by doing back translation. In a line with, Zhang \& C [10] proposes that back translating simply refers to the process of translating a translated text back to its original language. In addition, students enjoyed the learning process since they knew the gaps between their knowledge and the language itself.

Regarding the explanation above, it can be concluded that back translation gives significant effect toward students' translation achievement. In general, back translation is good to be applied in teaching translation since the students learn and understand both SL and TL languages deeply.
On the other hand, the students who are taught by using small group discussion technique did not get better result in translation. In this case, they had a hard time in choosing appropriate words in translating since they had gaps in information. Moreover, they do not insist to revise their works because they found it the same. Consequently, their translation were still literal than it should have.

\section{CONCLUSION}

The students who are taught by using back translation technique got better score than the students who are not. Back translation technique allows the students to compare and see their translation with the real text so that they became aware of the appropriate translation in particular conditions. Implementing back translation technique will undoubtedly improve students' translation achievement. However, there may be another variable that can influence the result of the test.

\section{ACKNOWLEDGMENT}

I would like to dedicate my sincere gratitude and appreciation to those who have given their contribution. My deepest gratitude goes to Prof. Dr. Hermawati Syarif, M.Hum, Dr. Kurnia Ningsih, M.A, and Dr. Hamzah, M.A., M.M as my advisors, who have helped me, given a great deal of time, guidance and valuable pieces of advice. And also Dr.Jufri, M.Pd and Dr. Havid Ardi, M.Hum as the examiners and contributors who have given contributions and suggestions for the improvement of this work.

\section{REFERENCES}

[1] X. Liu and G. Zhao, "A Comparative Study of Emotion Metaphors between English and Chinese," 
Theory Pract. Lang. Stud., vol. 3, no. 1, pp. 541-548, 2013.

[2] H.-Y. Chen and J. Boore, "Translation and backtranslation in qualitative nursing research: Methodological review," J. Clin. Nurs., vol. 19, pp. 234-239, 2009.

[3] U. Ozolins, "Back Translation As a Means of Giving Translators a Voice," Int. J. Transl. Interpret. Res., vol. 1, no. 2, pp. 1-13, 2009.

[4] P. Newmark, A Textbook of Translation by Peter Newmark (1). Great Britain: Prentice HaH International vUIO Ltd, 1988.

[5] D. Panou, "Equivalence in Translation Theories: A Critical Evaluation," Theory Pract. Lang. Stud., vol. 3, no. 1, pp. 1-6, 2013.

[6] E. Calvo, "Translation and/or Translator Skills as Organising Principles for Curriculum Development Practice," J. Spec. Transl., vol. 1, no. 16, pp. 5-25, 2011.

[7] A. Supriyadi, "Kualitas Hasil Penerjemahan Kelompok Mahasiswa S2 UNM-Malang (Studi Kasus Hasil Penerjemhan Buku Teks 'Approaches to Discourse' oleh Deborah Schiffrin)," Cakrawala Bahasa-Jurnal Pendidik. Bhs. dan Sastra, vol. 5, no. 2, pp. 113-140, 2016.

[8] H. Fry, S. Ketteridge, and S. Marshall, $A$ Handbook for Teaching \& Learning in Hinger Education Second Edition. United States: Kogan Page, 2003.

[9] D. W. Chapman and J. F. Carter, "Translation Procedures for the Cross Cultural Use of Measurement Instruments," Educ. Eval. Policy Anal., vol. 1, no. 3, pp. 71-76, 1979.

[10] Y. Zhang and C. G. C, "Back translating: An Integrated Approach to Focus Learners' Attention on Their L2 Knowledge Gaps.," English Teach. Forum, no. 1, pp. 30-34, 2014.

[11] L. S. Musianto, "Perbedaan Pendekatan Kuantitatif dengan Pendekatan Kualitatif dalam Metode Penelitian," J. Manaj. dan Wirausaha, vol. 4, no. 2, pp. 123-136, 2002.

[12] N. Aprilia and H. Indrijati, "Hubungan antara Kecerdasan Emosi dengan Perilaku Tawuran pada Remaja Laki-Laki yang Pernah Terlibat Tawuran di SMK 'B' Jakarta," J. Psikol. Pendidik. dan Perkemb., vol. 3, no. 1, pp. 1-11, 2014. 